\title{
Combined Effects of Ionizing Radiation and Cycloheximide on Gene Expression
}

Gayle E. Woloschak ${ }^{1}$, Paolo Felcher ${ }^{2}$, and Chin-Mei Chang-Liu
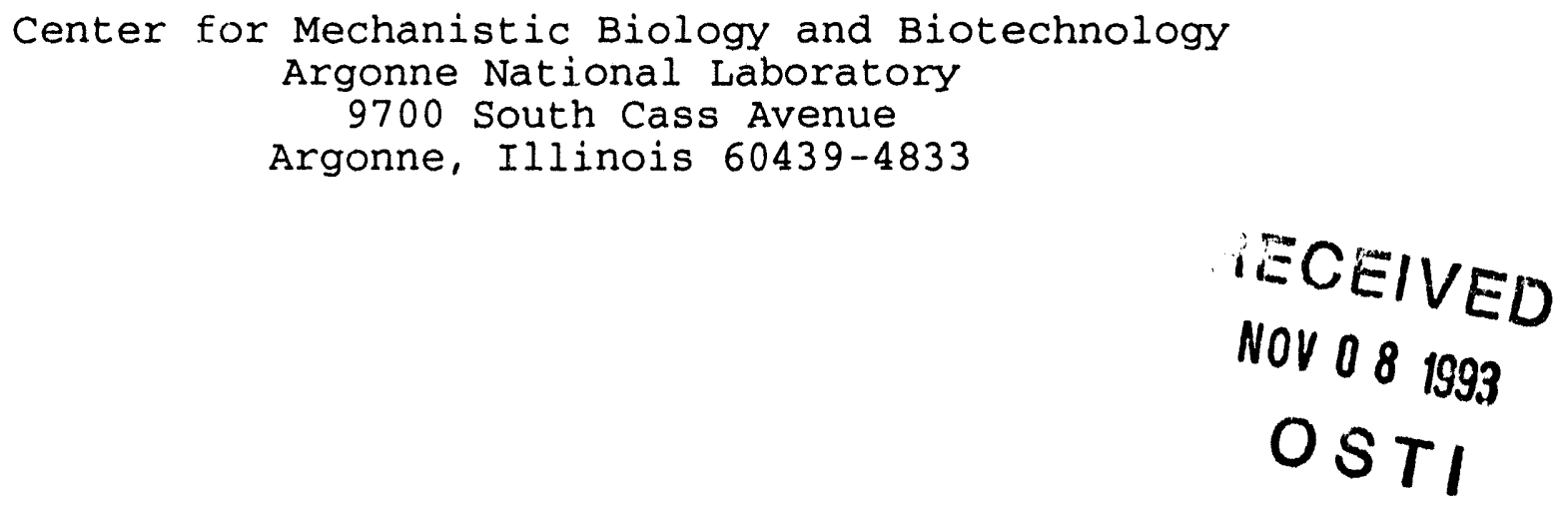

No. of Copies Submitted: $\quad 4$

No. of Manuscript Pages: $\quad 16$

Tables: 2

Figures: $\quad 4$ 
Running Title: Radiation-induced Gene Expression

${ }^{1}$ To whom correspondence should be addressed: Gayle E. Woloschak, Center for Mechanistic Biology and Biotechnology, Argonne National Laboratory, 9700 South Cass Avenue, Argonne, Illinois 60439-4833. Telephone (708)252-3312 - Fax (708)252-3387.

${ }^{2}$ Work done while a student in the laboratory of G. E. Woloschak. Paolo Felcher's current address: Baylor University of Medicine, Houston, Texas

Abbreviations:

$\begin{array}{ll}\text { CHX - } & \text { cycloheximide } \\ \text { SHE cells - } & \text { Syrian hamster embryo cells } \\ \text { LET - } & \text { linear energy of transfer } \\ \text { SDS - } & \text { sodium dodecyl sulfate } \\ \text { poly }(A)+\text { RNA - polyadenylated RNA }\end{array}$

\section{DISCLAIMER}

This report was prepared as an account of work sponsored by an agency of the United States Government. Neither the United State: Government nor any agency thureof, nor any of their employees, makes any warranty, express or implied, or assumes any legal liability or responsibility for the accuracy, completeness, or usefulness of any informaiion, apparatus, product, or process disclosed, or represents that its use would not infringe privately owned rights. Reference herein to any specific commercial product, process, or service by trade name, trademark, manufacturer, or otherwise does not necessarily constitute or imply its endorsement, recommendation, or favoring by the United States Government or any agency thereof. The views and opinions of authors expressed herein do not necessarily state or reflect those of the United States Government or any agency thereof. 


\section{ABSTRACT}

WOLOSCHAK, G. E., FELCHER, P., and CHANG-LIU, C-M. Combined Effects of Ionizing Radiation and Cycloheximide on Gene Expression. Radiat. Res.

Experiments were done to determine the effects of ionizing radiation exposure on expression of genes following exposure of Syrian hamster embryo (SHE) cells to the protein synthesis inhibitor cycloheximide (including such genes as $\beta$-actin, $c-f o s$, H4-histone, $\mathrm{c}-m y c, c-j u n, \mathrm{Rb}$, and $\mathrm{p} 53)$. Results revealed that when ionizing radiations (either fission-spectrum neutrons or $\boldsymbol{\gamma}$-rays) were administered $15 \mathrm{~min}$ following the cycloheximide treatment of SHE cells, the radiation exposure reduced cycloheximide-mediated gene induction for most of the induced genes studied (c-fos, H4histone, c-jun). In addition, dose-rate differences were found when radiation exposure most significantly inhibited the cycloheximide response. Our results suggest (1) that ionizing radiation does not act as a general protein synthesis inhibitor and (2) that the presence of a labile protein is required for the maintenance of transcription and mRNA accumulation following radiation exposure, especially for radiation administered at high dose-rates. 


\section{INTRODUCTION}

The effects of cycloheximide and ionizing radiation treatments alone or combined on specific gene expression were examined in Syrian hamster embryo (SHE) cells. Previous work by ourselves and others has shown that expression of a variety of genes is modulated following exposure to ionizing radiation (1-5), although the actual role of this specific gene response is unknown. Several groups (2, 4) have suggested that modulation of the expression of specific genes in response to ionizing radiation may contribute to some critical cellular repair function associated with DNA damage or may enhance cell survival following exposure to the insult. The mechanism(s) by which genes are modulated following exposure to radiation also is not understood, though several groups have postulated a role for radiation responsive elements located at or near the $5^{\prime}$ end of the modulated genes $(1,4)$. Previous work from our group has identified a general transcriptional repression that accompanies ionizing radiation exposure $(1,2)$, though the mechanism(s) responsible for this repression also has not yet been defined. Previous dose-rate studies have shown that radiation exposures given at low dose-rates are more repressive for total transcription that those given at high dose-rates $(1,2)$, prompting us to examine dose-rate effects in the studies reported here.

Cycloheximide routinely has been used as a probe for the role of protein synthesis in cellular responses. Several reports have documented genes induced in response to cycloheximide, including 
genes such as $\beta$-actin, c-fos, c-jun, c-myc, and histones (6-9). Genes induced by protein synthesis inhibitors are considered to be regulated intracellularly in a negative manner by one or more labile proteins. In the work reported here, we examined the effects of ionizing radiation and/or cycloheximide treatment on specific gene expression. Our experiments were designed to determine (a) whether ionizing radiation and cycloheximide had similar effects on gene expression in SHE cells and (b) whether protein synthesis inhibition would influence the cellular transcriptional response following ionizing radiation exposure. For the experiments done in this work, we chose genes known to be induced by cycloheximide treatment.

Much past work in our laboratory $(1,2,10-13)$ has compared effects of high- and low-LET radiation as well. as the effects of high and low dose-rates of radiation exposure on parameters of gene expression. In the work reported here, we similarly evaluated the influence of LET and radiation dose-rate on gene expression in the presence or absence of cycloheximide.

\section{MATERIALS AND METHODS}

Cells and Culture Conditions

These experiments were designed to examine the effect of radiation exposure on the expression of specific genes in SHE 
fibroblasts. These cells are normal, diploid cells that can be neoplastically transformed by ionizing radiation $(14,15)$.

All cell cultures were maintained in Dulbecco's modified Eagle medium, which contains 108 fetal calf serum, $2 \mathrm{~mm}$ glutamine, $100 \mu / \mathrm{ml}$ penicillin, and $100 \mu / \mathrm{ml}$ streptomycin. Cells were grown to confluence and $48 \mathrm{~h}$ before irradiation they were placed in a medium containing 1.08 fetal calf serum to maintain them in plateau phast. Studies of preirradiated SHE cells grown under this protocol showed them to be a mixed population of fibroblasts with over 90-958 of the cells in the $G_{0} / G_{1}$ stage of the cell cycle as described previously $(1,4)$. Cells were from passage 1 or 4 . Previous studies have shown no differences with regard to transcriptional responses between cells from these passages $(1,2)$.

\section{Radiation and Cycloheximide Treatments}

Cells plated in $100 \mathrm{~mm}$ Petri plates containing $10 \mathrm{ml}$ of medium were irradiated with ${ }^{60} \mathrm{Co} \gamma$-rays or fission spectrum neutrons 10.85 $\mathrm{MeV}$ from the JANUS reactor. The actual design of the JANUS reactor and its dosimetry has been reported previously (16). All irradiations were performed at room temperature on cells in plateau phase (>958 $G_{0}-G_{1}$ cells); equitoxic doses of neutrons and $\gamma$-rays were selected on the basis of survival data (15). Doses and doserates were chosen on the basis of the significant frequency of morphological transformation as determined in a 10-day colony assay (15). For $n_{0}$, a dose of 12 cGy was administered at either 0.5 
$\mathrm{cGy} / \mathrm{min}$ or $12 \mathrm{cGy} / \mathrm{min}$; for $\gamma$ rays, a dose of 50 cGy was administered at either 1 or 14 cGy/min. These doses of radiation cause a decrease in sruvival no greater than 5\%. Control cells were taken to the radiation chamber, but not exposed to radiation. Fifteen minutes before irradiation, $100 \mu \mathrm{g} / \mathrm{ml}$ of cycloheximide (CHX) in PBS was added to the CHX-treated group of cells, while an equal volume $(1 \mathrm{ml})$ of $\mathrm{PBS}$ was added to the controls. For all experiments reported here, $60 \mathrm{~min}$ after the completion of the irradiation, the cells were harvested.

Purification of RNA and Northern Blots

RNA was prepared by isolation in $6 \mathrm{M}$ guanidine isothiocyanate, extraction with phenol, and precipitation with $3 \mathrm{M}$ sodium acetate $(\mathrm{pH} 6.0)$ as previously described $(1,2,3)$. Poly $(A)+$ RNA was isolated by oligodeoxythymidylate cellulose chromatography until no unbound material absorbing at $254 \mathrm{~nm}$ was detected. RNA was separated by using formaldehyde agarose gel electrophoresis as described previously $(1,2,3)$.

Northern transfers were performed as described previously (1-3). Blots were hybridized to ${ }^{32} \mathrm{P}-n$ ick-translated or oligolabeled cDNA probes. Hybridization conditions were 508 deionized formamide, $0.75 \mathrm{M} \mathrm{NaCl}, 75 \mathrm{mM}$ sodium citrate, 25-50 mM sodium phosphate $(\mathrm{pH} 6.5), 0.28$ SDS, 0.28 bovine serum albumin, 0.28 ficoll, 0.28 polyvinylpyrrolidone, and $50 \mu \mathrm{g} / \mathrm{ml}$ sonicated, denatured herring sperm DNA at $43^{\circ} \mathrm{C}$. Prior to hybridization, all 
labeled probes were heat denatured at $90^{\circ} \mathrm{C}$ for $5 \mathrm{~min}$. After hybridization, nonspecific binding was reduced by washing the hybridized blots three times for $1 \mathrm{~h}$ each at $43^{\circ} \mathrm{C}$ in $45 \mathrm{~mm}$ sodium citrate $(\mathrm{pH} 7.4), 0.45 \mathrm{M} \mathrm{NaCl}, 0.2 \quad \%$ ficoll, $0.2 \%$ polyvinylpyrrolidone, 0.28 bovine serum albumin, $50 \mu \mathrm{g} / \mathrm{ml}$ herring sperm DNA and 0.18 SDS. The blots were then dried and exposed to $\mathrm{X}$ ray film at $-20{ }^{\circ} \mathrm{C}$.

Blots were washed three times in hybridization buffer before rehybridization to a different probe. Relative quantitation of the hybridized probe was determined by using a Hirschmann microdensitometer. All results are averaged from three independent observations.

Although equal amounts of RNA by weight, as determined by spectrophotometry, were loaded into each well of a given gel, we found sufficient variation from one preparation to another to make poly $(A)+$ analysis essential. We used mRNA analysis systems to measure the molir concentration of RNA with 3'poly(A) tails (Molecular Genetics Resources) were used for all poly $(A)+$ RNA preparations, with only RNA samples showing equimolar concentrations of poly $(A)+$ RNA loaded onto the same gel.

CDNA Ciones

We gratefully acknowledge the gifts of the following clones made available to us: isotype-specific actin cDNA clones (pHFßA- 
3'ut, pHFYA-3'ut) were obtained from Dr. L. Kedes (Stanford University, Palo Alto, CA), H4-histone from Dr. Stein (Univ. of Massachusetts, Worcester, MA), c-jun from Dr. Lamph (Salk Institute, San Diego, CA), p2k3.8 mouse Rb clone from Dr. Dryja (Harvard Univ., Boston, MA), and fos, myc, and p53 probes from American Type Culture collection (Rockville, MD) . 


\section{RESOLTS}

Effects of Ionizing Radiation on Cycloheximide-inducible genes

SHE cells pretreated for $15 \mathrm{~min}$ with $100 \mu \mathrm{g} / \mathrm{ml}$ cycloheximide were exposed to equitoxic doses of $\gamma$-rays pr JANUS fission-spectrum neutrons administered at either high orlow dose-rates. In all experiments, RNA was harvested $1 \mathrm{~h}$ following completion of the irradiation. Expression of a variety of genes known to be induced by iycloheximide was determined by Northern blots, depicted in Fig. 1. Quantitation of these and other successive blots was done by microdensitometry with average results (from three determinations) reported in Table $I$. Hybridization to the rRNA probe revealed that equal amounts of RNA were on the blots. Two genes known in the literature $(6,7)$ to be induced by cycloheximide, $c-i n y c$ and $\beta$-actin, were not found to be induced under these conditions. Interestingly, radiation exposure at high dose-rates repressed expression of these two genes in the presence of cycloheximide, when compared to untreated cells. Other genes induced by cycloheximide in our cell system (c-jun, c-fos, H4histone) showed a dose-rate effect of radiation exposure on mRNA accumulation in the absence of cycloheximide, c-fos, and H4histone. For all three genes, exposure to either $\gamma$-rays or neutrons administered at high dose-rates also suppressed cycloheximide-induced mRNA accumulation relative to cells treated with cycloheximide alone, radiation alone, or even cycloheximide combined with radiation administered at a high dose-rate. For this 
set of genes, few differences were evident when comparing high-LET neutrons and low-LET $\gamma$-rays radiation.

Effects of radiation on other transcripts

We also examined the effects of cycloheximide and radiation on genes not known to be inducible by cycloheximide (K-ras, Rb, p53 $\alpha$ tubulin). Microdensitrometric results of Northern blots are reported in Table II. For K-ras, $\alpha$-tubulin, and to a lesser extent $\mathrm{Rb}$ transcripts, a dose-rate effect on cells pretreated with cycloheximide was evident. Radiation exposures administered at a high dose-rate repressed accumulation of $\mathrm{k}$-ras and $\alpha$-tubulin RNA in cycloheximide pretreated cells. For Rb-specific mRNA, the doserate effect was only partially evident, while for p53-mRNA neither cycloheximide nor radiation treatments had any effect. It should be noted that low dose-rate radiation exposures had no effect in the absence of cycloheximide.

\section{DISCOSSION}

The experiments reported here were designed to examine the combined effects of protein synthesis inhibition and radiation exposure on specific mRNA accumulation. We compared high-LET neutron and low-LET $\gamma$-ray exposures administered at either high or Low dose-rates. Equitoxic doses of $\gamma$-rays and neutrons were chosen to allow for accurate intra-experimental comparisons. Past work in our laboratory has documented several examples of transcriptional 
inhibition evident in SHE cells following exposure to either highor low-LET radiation $(1,3)$. Some have suggested that this inhibition is merely the result of the inhibition of protein synthesis evident in cells following radiation exposure (4). Our results clearly show that radiation exposure and inhibition of protein synthesis have some dramatically different consequences for cellular transcription and mRNA accumulation.

Under our conditions, induction of $c$-myc and $\beta$-actin by cycloheximide alone was not evident, as had reen reported by others in the literature $(6,7)$. The reasons for this are not known, though we believe that SHE cells are generally "slow starters" for mRNA induction and, therefore, induction of these two genes within the first $80 \mathrm{~min}$ following cycloheximide treatment (as was done in all experiments reported here) may not be adequate to identify induced mRNA. The fact that c-fos induction is evident at this relatively late timepoint (c-fos peaks in other fibroblasts at 15 min following cycloheximide exposure) supports this idea (6). It is interesting, though, that radiation exposures at high dose-rates for cycloheximide-pretreated cells caused a decreased expression of $c-m y c$ and $\beta$-actin; this suggests that the cellular mechanisms required to induce high-level expression of $c$-myc and $\beta$-actin following radiation exposure may require the presence and/or intervention of some as-yet-unidentified labile protein.

The high dose-rate effect observed for the transcripts not affected by cycloheximide was also observed for transcripts whose 
accumulation was induced by inhibition of protein synthesis-notably c-jun, c-fos, H4-histone. These results similarly suggest the involvement of a labile protein in the maintenance of transcription and mRlva accumulation following radiation exposure.

Past work has documented differences between high-and low-LET radiation when examining gene expression $(1,2,3)$. The results reported here provide little evidence for such differences being mediated at the level of a labile protein product, though doses and kinetics were chosen in such a way as to minimize LET differences. The dramatic differences between radiation exposure at high and low dose-rates additionally suggest different dose-rate dependent mechanisms of radiation-mediated transcriptional inhibition. Experiments are underway to test this in more detail.

\section{ACKNOWLEDGEMENTS}

The authors would like to thank Kay Bexson for her excellent secretarial assistance in preparing this manuscript, Gordon Holmblad for assistance in all irradiations, and Drs. Frank Collart, Thomas seed, and Claudia Libertin for review prior to submission. Work supported by the U.S. Department of Energy, Office of Health and Environmental Research, under contract No. W-31-109-ENG-38. 


\section{REFERENCES}

1. G. E. Woloschak, C-M. Liu, and P. Shearin-Jones, Regulation of protein kinase $C$ by ionizing radiation. Cancer Res. 50, 3963$3967(1990)$.

2. G. E. Woloschak, C-M. Liu, P. S. Jones, and C. A. Jones, Modulation of gene ex rassion in Syrian hamster embryo cells following ionizing radiation. Cancer Res. 50, 339-344 (1990).

3. G. E. Woloschak, P. Shearin-Jones, and C-M. Chang-Liu, Effects of ionizing radiation on expression of genes encoding cytoskeletal elements: kinetics and dose effects. Molecular Carcinogenesis 3, 374-378 (1990).

4. A. J. Fornace, Jr., I. Alamo, Jr., and C. M. Hollander, DNA damage-inducible transcripts in mammalian cells. Proc. Natl. Acad. SCi. USA 85, 8800-8804 (1988).

5. C. M. Hollander and A. J. Fornace, Jr., Induction of fos RNA by DNA-damaging agents. Cancer Res. 49, 1687-1692 (1989).

6. M. E. Greenberg and E. B. Ziff, Stimulation of $3 T 3$ cells induces transcription of the c-fos proto-oncogene. Nature 311 , $433-438(1984)$.

7. P. K. Elder, L. J. Schmidt, T. Ono, and M. J. Getz, Specific stimulation of actin gene transcription by epidermal growth 
factor and cycloheximide. Proc. Nat1. Acad. SCi. USA 81, $7476-7480(1984)$.

8. M. Linial, N. Gunderson, and M. Groudine, Enhanced transcription of $c-m y c$ in bursal lymphoma cells requires continuous protein synthesis. Science 230, 1126-1132 (1985).

9. A. M. Zubiagra, E. Münoz, and B. T. Huber, Superinduction of IL2 gene transcription in the presence of cycloheximide. $J$. Immunol. 146, 3857-3863 (1991).

10. G. E. Woloschak and C-M. Chang-Liu, Differential modulation of specific gene expression following high- and low-LET radiations. Radiat. Res. 124, 183-187 (1990).

11. G. E. Woloschak and C-M. Chang-Liu, Expression of cytoskeletal elements in proliferating cells following radiation exposure. I. J. Radiat. Biol. 59, 1173-1183 (1991).

12. J. Panozzo, D. Bertoncini, D. Miller, C. R. Libertin, and G. E. Woloschak, Modulation of expression of virus-like elements following exposure of mice to high- and low-LET radiations. Carcinogenesis 12, 801-804 (1991).

13. G. E. Woloschak, C-M. Chang-Liu, J. Panozzo, and C. R. Libertin, Low doses of neutrons induce changes in gene expression. Radiat. Res., in press. 
14. C. Borek, E. J. Hall, and H. H. Rossi, Malignant transformation in cultured hamster embryo cells produced by $\mathrm{X}$ rays, $430-\mathrm{keV}$ monoenergetic neutrons, and heavy ions. Cancer Res. 38, 2997-3005 (1978).

15. C. A. Jones, Morphological transformation of Syrian hamster embryo cells following acute or protracted exposures to fission-spectrum neutrons. In: Radiat. Res., Proceedings of the 8th International Congress of Radiation Research, Edinburgh, vol. 1, p. 132. Philadelphia: Taylor \& Francis, 1987 .

15. F. A. Williamson and N. A. Frigerio, Field mapping and depth dosimetry in the JANUS high flux irradiation room, a fast neutron facility for biological research. In: Proceedings of the First Symposium on Neutron Dosimetry in Biology and Medicine (G. Burger, H. Schraube, and H. G. Ebert, Eds.), p. 743. Commission of the European Communities, Luxembourg. 1972 . 


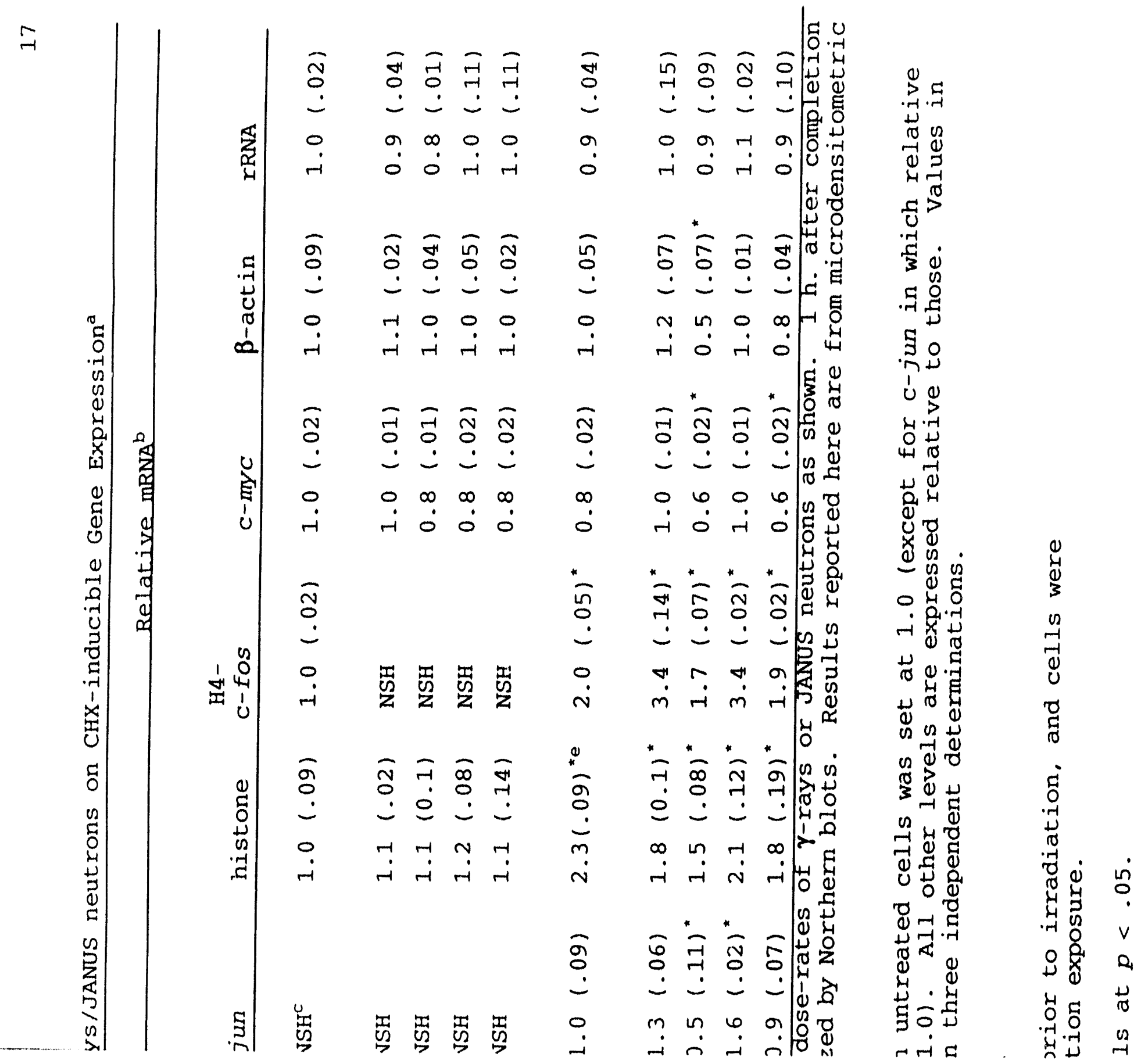




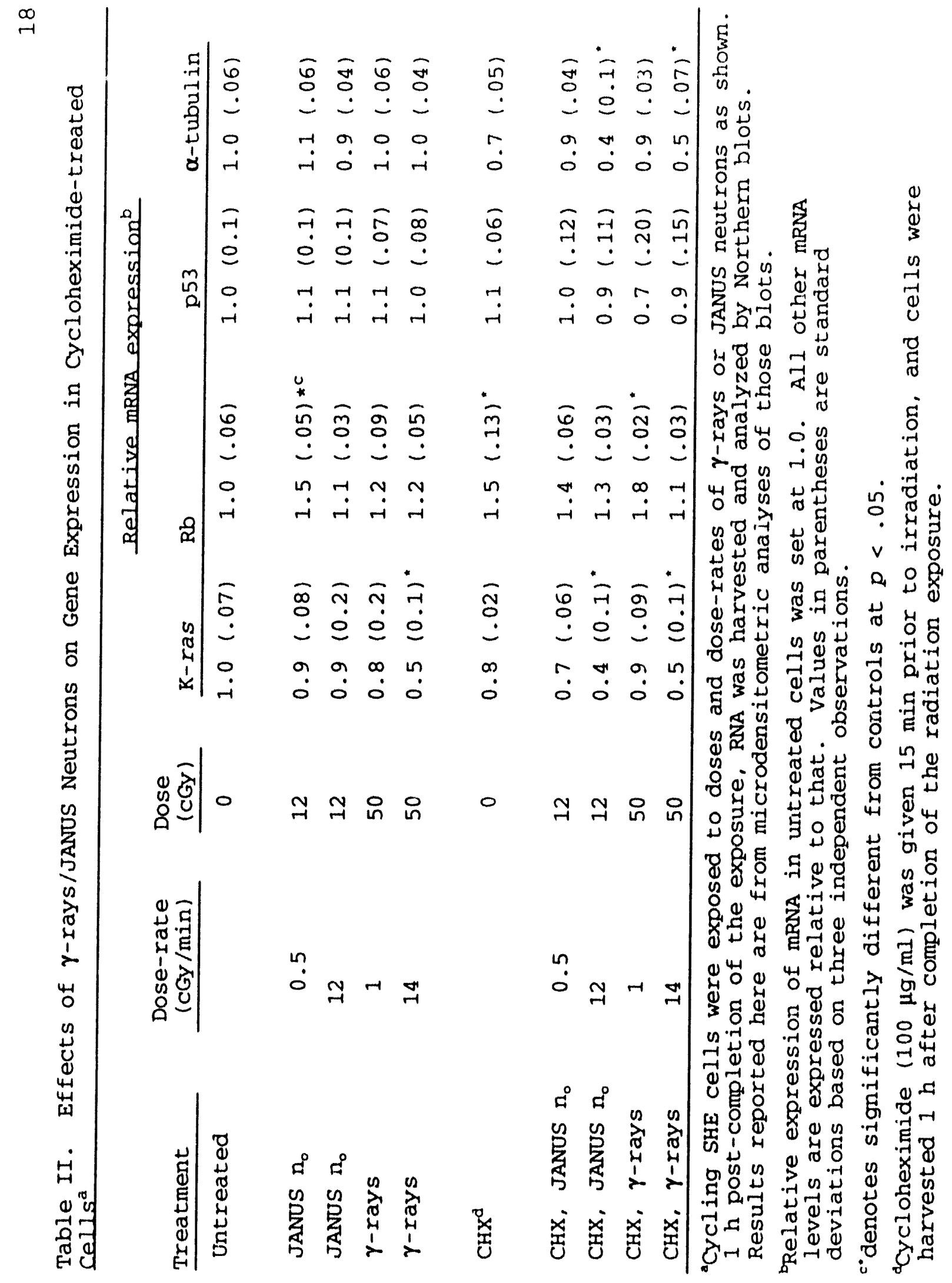


Figure 1. Northern blots examining expression of (A) C-jun, (B) H4-histone (C) $\mathrm{C}$-fos, and (D) $c-m y c$ in the presence (CHX) or absence of cycloheximide $(100 \mu \mathrm{g} / \mathrm{ml})$. Doses and doserates of radiation are as follows: $\mathrm{Ln}_{0}, 12$ cGy JANUS neutrons, $0.5 \mathrm{cGY} / \mathrm{min} ; \mathrm{Hn}_{0}, 12 \mathrm{cGY}$ JANUS neutrons, 12 cGy/min; L $\gamma, 50$ cGy $\gamma$-rays, 1 cGy/min; H $\gamma, 50$ cGy $\gamma$-rays, 14 cGy/min. 
Fig. IA

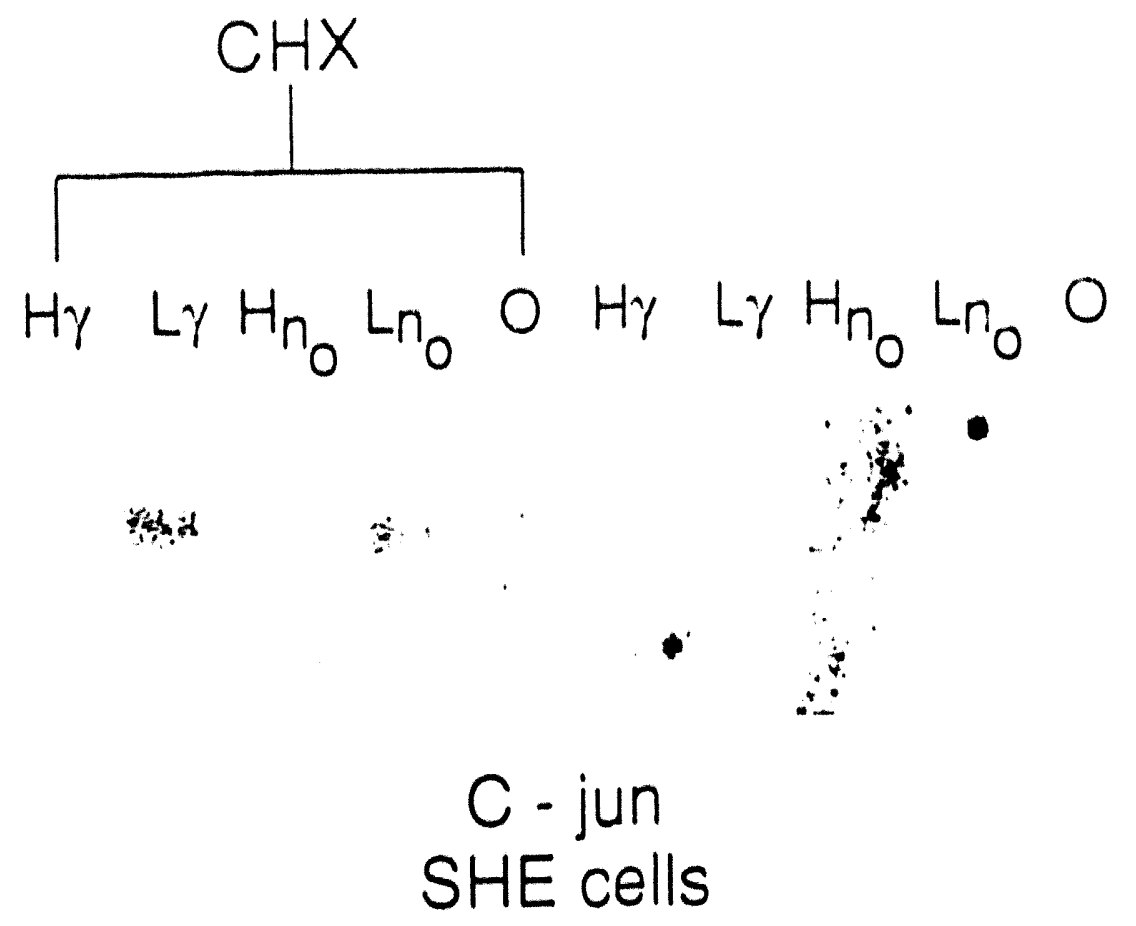

Fig. IB

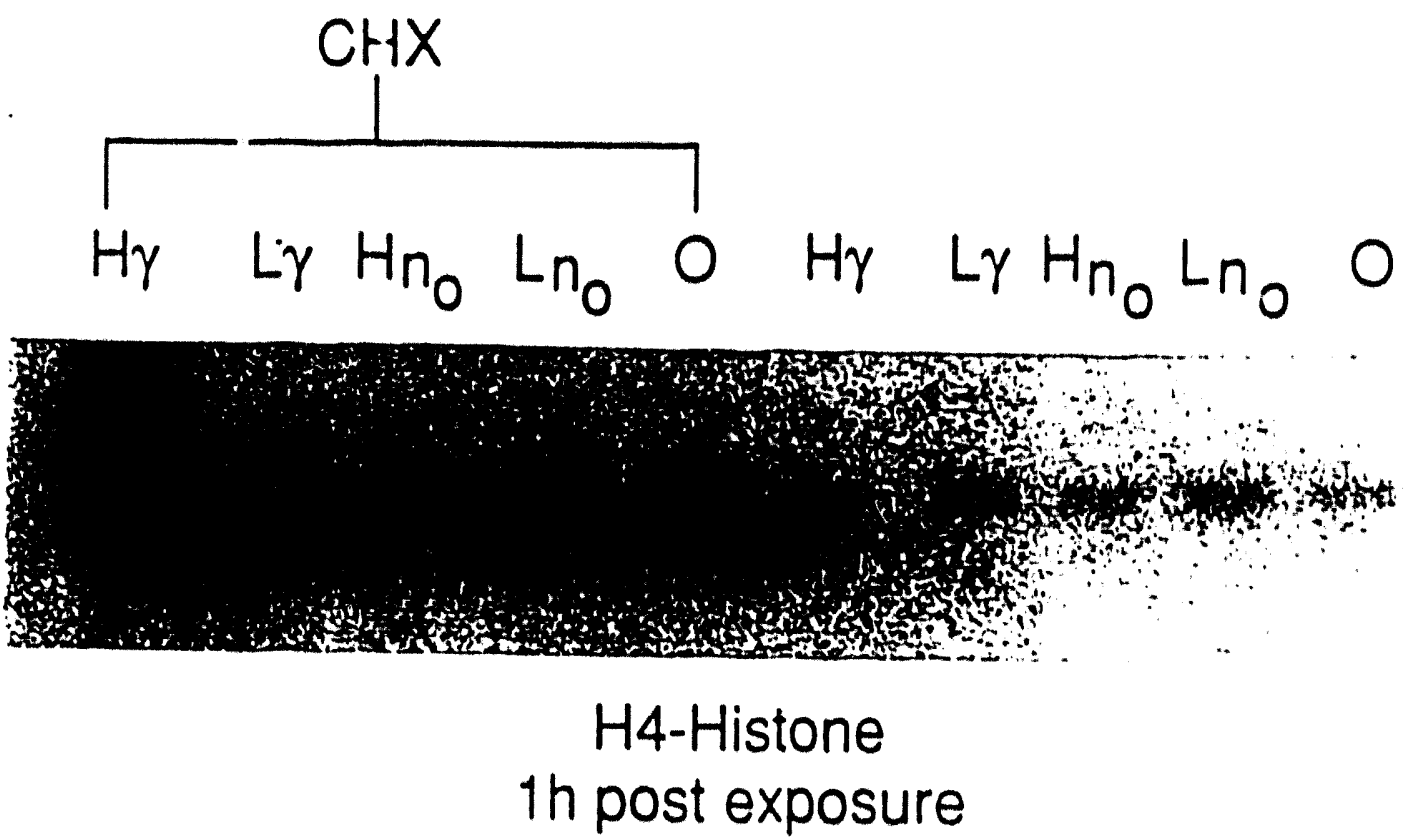




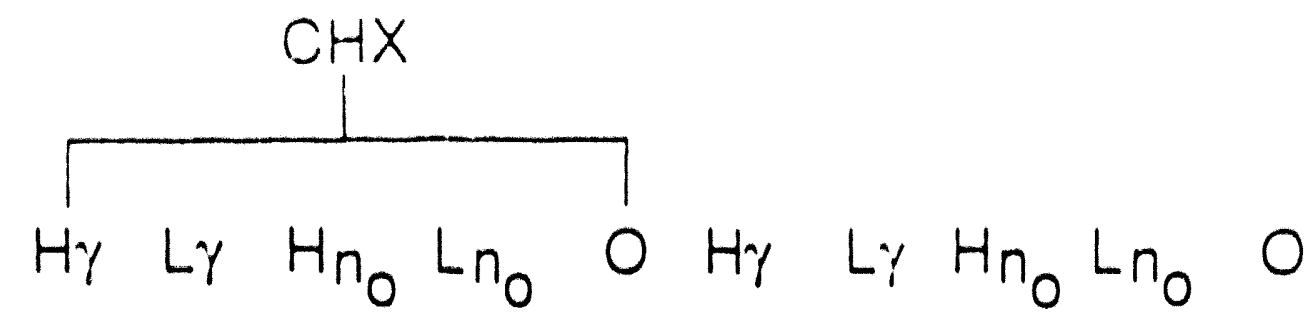

$3 y^{16}$

c-fos

Th post exposure

fig. 10

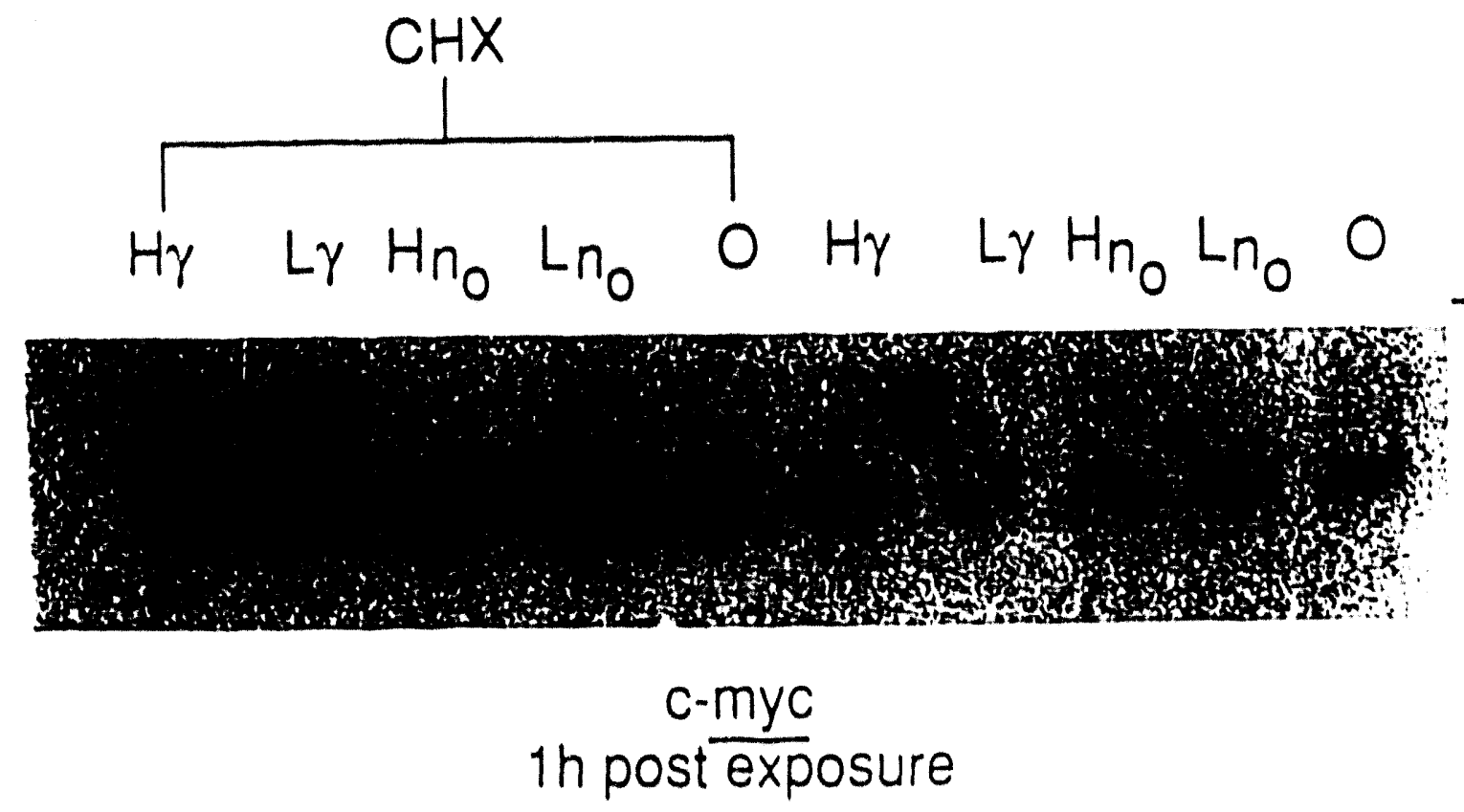




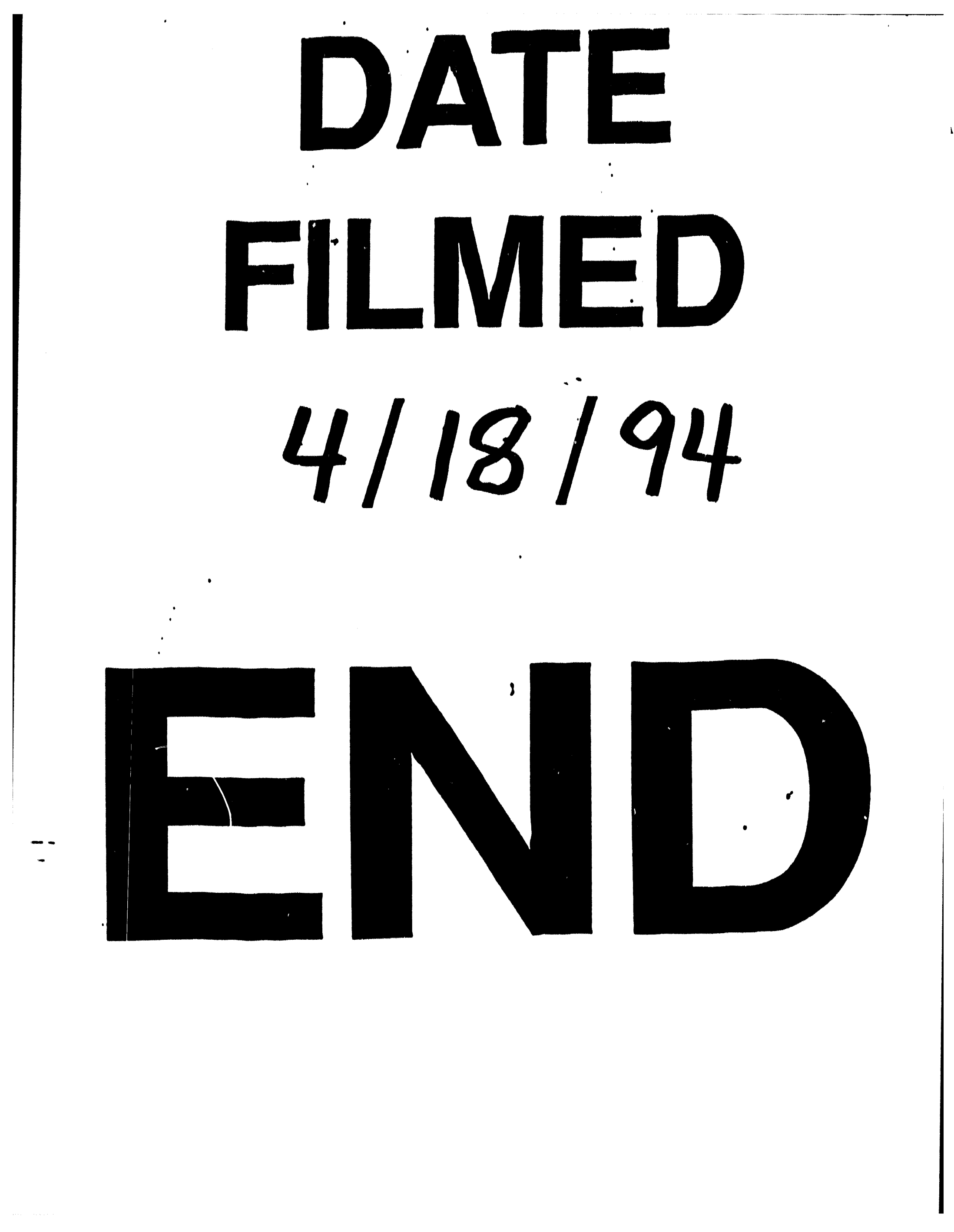




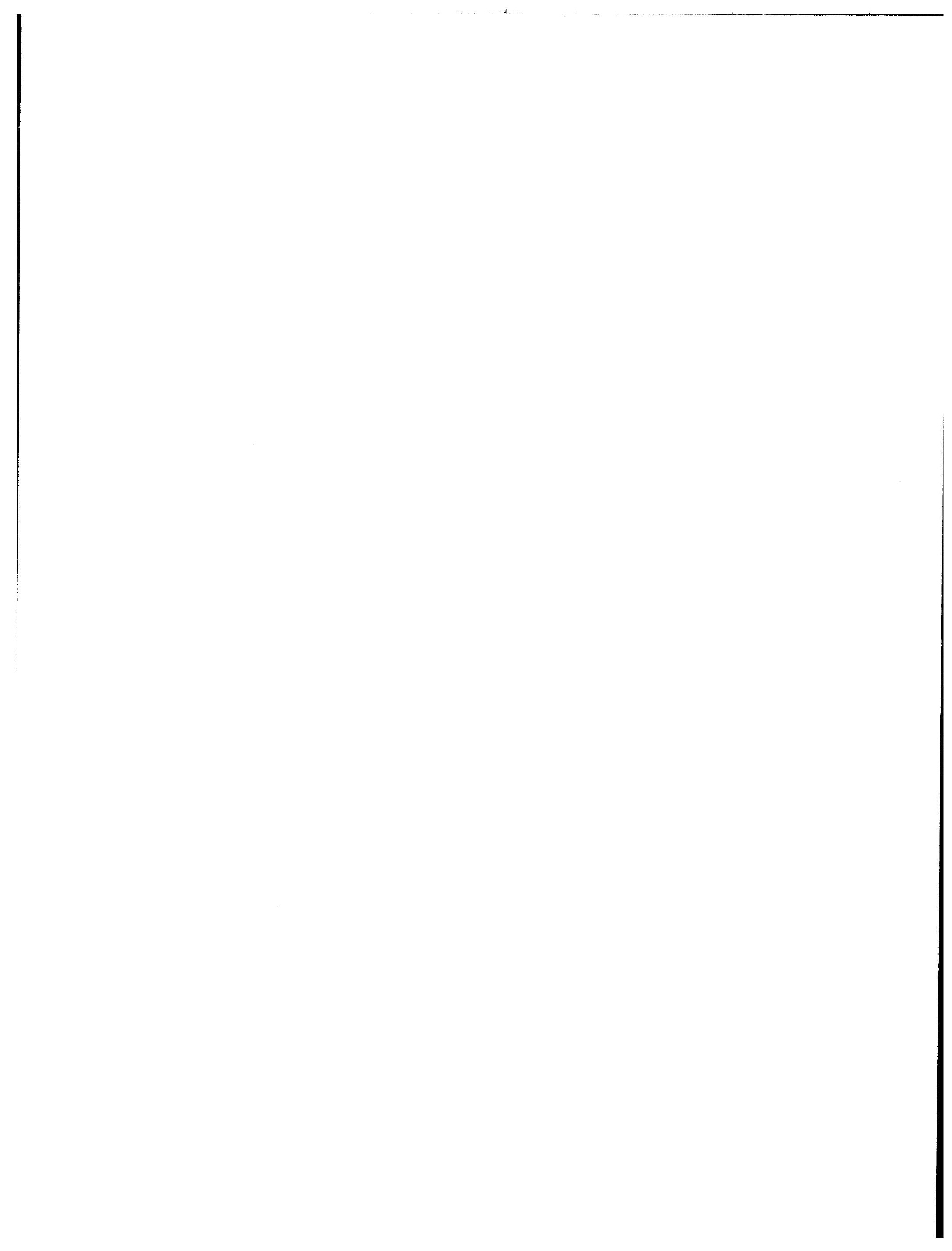

